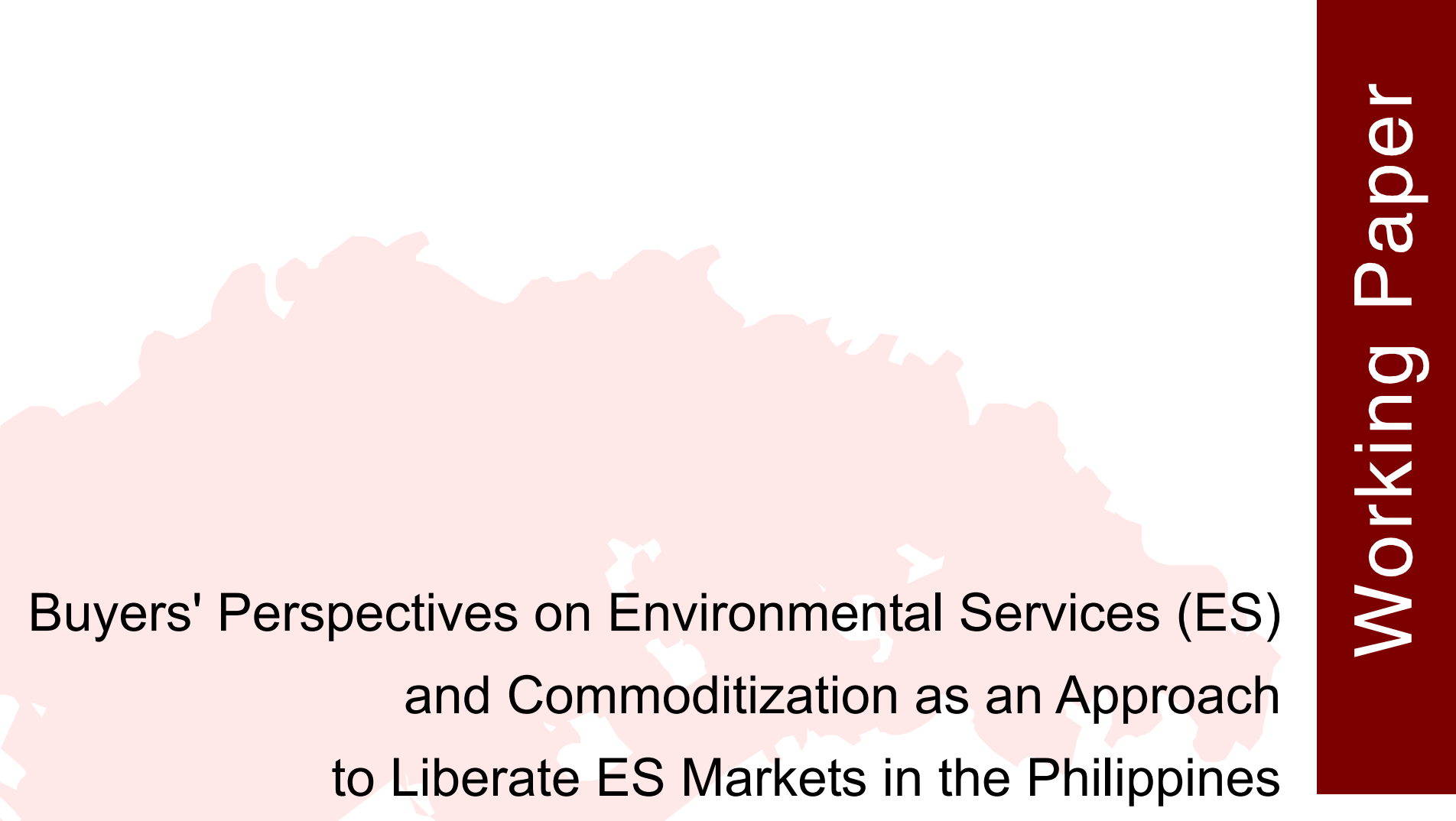

Grace B. Villamor, Meine van Noordwijk, Flordeliz Agra and Delia Catacutan 


\title{
Buyers' Perspectives on Environmental Services (ES) and Commoditization as an Approach to Liberate ES Markets in the Philippines
}

Grace B. Villamor, Meine van Noordwijk, Flordeliz Agra and Delia Catacutan

\author{
(C) ICRAF Southeast Asia 2007
}

ICRAF Working Paper Number 51 
Correspondence: g.villamor@cgiar.org

(C) Copyright ICRAF Southeast Asia

\section{World Agroforestry Centre}

Transforming Lives and Landscapes

ICRAF Southeast Asia Regional Office

Jl. CIFOR, Situ Gede, Sindang Barang, Bogor 16680

PO Box 161, Bogor 16001, Indonesia

Tel: 62251 625415, fax: 62251625416

Email: icraf-indonesia@cgiar.org

ICRAF Southeast Asia website: http://www.worldagroforestrycentre.org/sea

\section{Disclaimer}

This text is a 'working paper' reflecting research results obtained in the framework of ICRAF Southeast Asia project. Full responsibility for the contents remains with the authors 


\section{Abstract}

A study was conducted to understand the perspectives of buyers on environmental services (ES) markets in the Philippines. A total of 25 companies involved in various ES markets served as respondents. Of these, 56 percent were from government-owned companies and 44 percent from privately-owned companies. The majority of these companies, mostly government-owned, are engaged in water services. Privately-owned companies are primarily engaged in biodiversity and provision of landscape beauty. Most companies or buyers are compelled to pay for ES by the mandate of law, or for regulatory compliance. Some companies view ES from a business perspective and are therefore motivated by the business case in ES markets, as well as some ethical values. A total of $84 \%$ of the respondent companies are convinced about the business case of the concept of Payments for Environmental Services (PES), but have differently interpreted this concept. On the buyers' side, a growing demand for ES is an important precondition in ES markets. Some ES beneficiaries perceived payments as a generous way of showing environmental awareness and advocacy. There are ES markets that have strong economic potential, and commoditization is seen as a viable approach to encourage them. A means to commoditize some environmental services to liberate ES markets is proposed in this study.

\section{Keywords}

Environmental services (ES) market buyers, commoditization, motivation, payments for environmental services (PES) 


\section{List of Abbreviations}

$\begin{array}{ll}\text { BFAD } & \text { Philippine Bureau of Food and Drugs } \\ \text { BIR } & \text { Bureau of Internal Revenue } \\ \text { CADT } & \text { Certificate of Ancestral Domain Title } \\ \text { CPPAP } & \text { Conservation of Priority Protected Areas Project } \\ \text { DENR } & \text { Department of Environment and Natural Resources } \\ \text { DOE } & \text { Department of Energy } \\ \text { ERC } & \text { Energy Regulatory Commission } \\ \text { ES } & \text { Environmental services } \\ \text { GEF } & \text { Global Environment Facilities } \\ \text { JBIC } & \text { Japan Bank for International Cooperation } \\ \text { LGU } & \text { Local Government Units } \\ \text { LWUWA } & \text { Local Water Utilities and Water Authority } \\ \text { MOA } & \text { Memorandum of Agreements } \\ \text { MWSS } & \text { Metropolitan Waterworks and Sewerage System } \\ \text { NCIP } & \text { National Commission on Indigenous Peoples } \\ \text { NGO } & \text { Non-government organization } \\ \text { NIA } & \text { National Irrigation Authority } \\ \text { NWRB } & \text { National Water Resource Board } \\ \text { PAWB } & \text { Protected Area and Wildlife Bureau } \\ \text { PES } & \text { Payments for environmental services } \\ \text { PO } & \text { People’s Organization } \\ \text { RUPES } & \text { Rewarding Upland Poor for Environmental Services } \\ \text { UNDP } & \text { United Nations Development Program } \\ & \end{array}$




\section{Acknowledgement}

The authors would like to express their gratitude to Ms. Roberta Gerpacio and Ms. Leimona Beria for their technical review of this report. 


\section{Content}

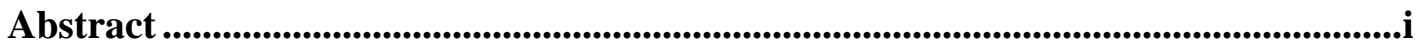

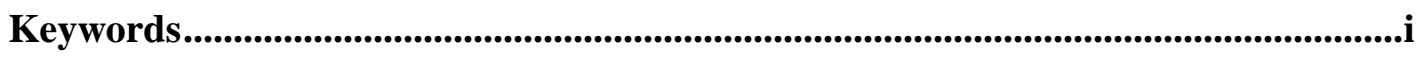

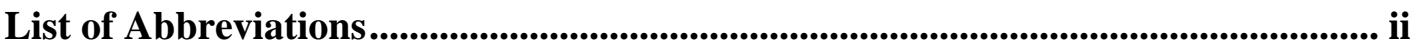

Acknowledgement ................................................................................................................................ iii

List of Figures ........................................................................................................................................v

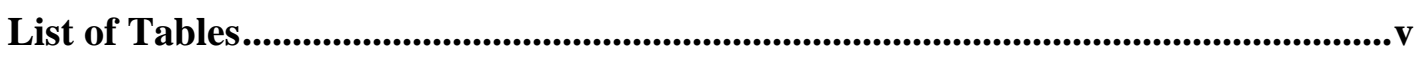

1. Introduction ......................................................................................................................1

ES Buyers: The Main Actor............................................................................................. 1

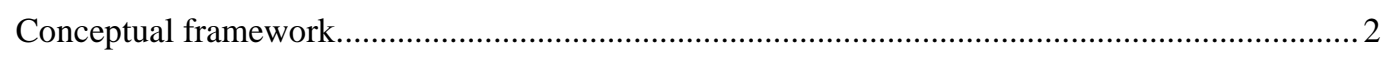

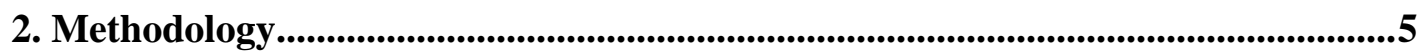

Data Gathering ................................................................................................................

Scope of the survey .........................................................................................................

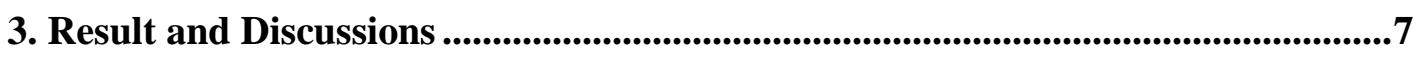

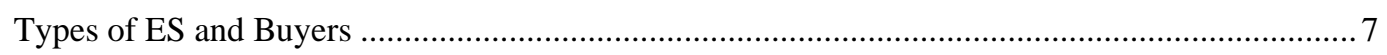

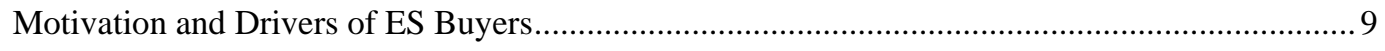

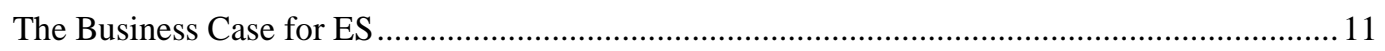

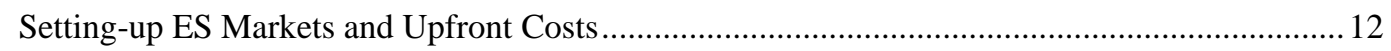

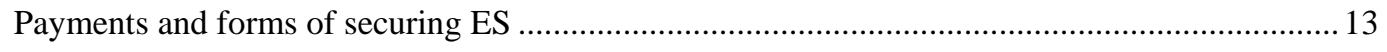

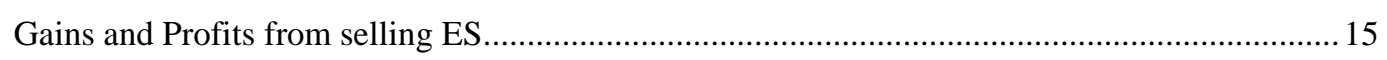

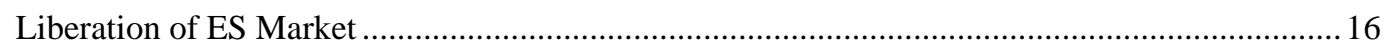

Constraints for ES Market Liberation........................................................................................ 16

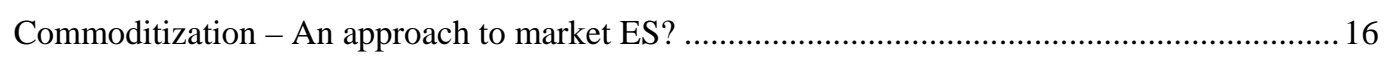

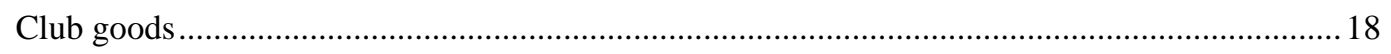

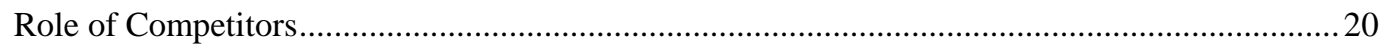

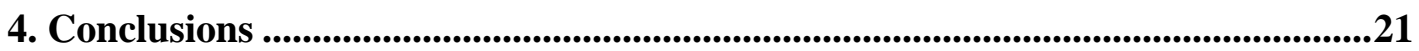

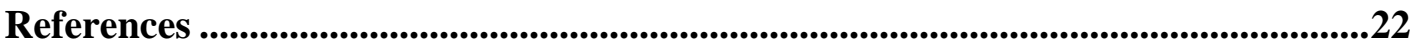

Appendix ................................................................................................................................2 23 


\section{List of Figures}

Figure 1. Relative importance of drivers for market development

(Source: Landell-Mills and Porras, 2002) ......................................................2

Figure 2. Relationship of the provider and beneficiaries of ES in a complex

landscape (van Noordwijk, 2005). .................................................................

Figure 3. Breakdown of companies identified for ES market survey. ..............................5

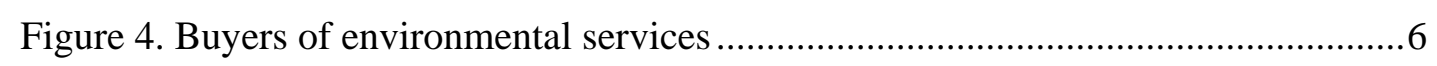

Figure 5. Percentage of companies engaged in ES markets..........................................

Figure 6. Number of companies and their motivations to pay for ES. ...........................10

Figure 7. Response of companies on strong business case for PES ..............................11

Figure 8. Concept of commoditization to market environmental services

(van Noordwijk in progress).....................................................................18

\section{List of Tables}

Table 1. Cases examined with various types of organizations and agencies in the ES market (Adopted from Boquiren, 2005) .........................................................4

Table 2. Type of environmental services and demand by type of company. ....................

Table 3. Responses from companies on how to articulate the business case of ES .......12

Table 3. Example of profits from engaging in ES markets (approximated values).......15

Table 4. Degree of rivalry and excludability of the ES................................................17

Table 5. Recommended commodities used to market ES (adopted from Landell-Mills \& Porras (2005) and based on the results of this survey)..............................19 



\section{Introduction}

There is growing interest in payments/ rewards for environmental services (P/RES). Costanza et al, (1997) classify environmental services into 17 major categories with functions and examples. They estimate an average annual contribution of \$33 trillion USD worth of ES to human welfare. These include provisioning (e.g. food, fiber, water, etc), regulating (e.g. climate, disturbance and water regulation), and cultural services (e.g. recreational, spiritual and educational) that directly affect people, as well as supporting services (e.g. carbon stocks) needed to maintain the other services. Among the major ES with existing formal and informal payment or reward schemes are watershed protection, biodiversity conservation, carbon sequestration and provision of landscape and seascape beauty. Within the last four years, the program on Rewarding Upland Poor for Environmental Services (RUPES) generated robust insights and lessons that contributed to a better understanding of the complex processes involved in creating or working in, ES markets. The RUPES study identifies four indivisible criteria for ES rewards/payments, namely: realistic; voluntary; conditional; and pro-poor. With these criteria, the goal of PES is to alleviate the poor conditions of upland people while conserving the landscapes for which these environmental services are being provided. Much is known about the different actors involved in the burgeoning ES markets - the buyers, sellers, and intermediaries. In this study, attention is focused on the former, in particular, the buyers' perspectives on ES markets. The underlying objective is to understand the motivations and drivers of ES buyers in the Philippines. This report describes the typical ES buyers and their buying schemes. Some studies on the universal motivation of buyers on PES have been conducted previously (Mulder, et al., 2006; Scher, et al., 2006) but this study further seeks to understand how to scale-up the investments of existing buyers in ES markets. It also proposes a new concept of commoditizing environmental services, to accelerate the liberation of ES markets.

\section{ES Buyers: The Main Actor}

Usually, beneficiaries or buyers pay very little for ES that have traditionally been seen as free because they have been produced by nature at no cost. The idea that nature subsidizes all production costs can be acceptable, albeit arguable, only when natural resources are constantly abundant and can be assumed to be eternally inexhaustible. Past and current use of natural resources has resulted in the dwindling of natural capacity, and the few environmental services that remain, operate at diminished levels. Payments or rewards are promising instruments to sustain ES provision while at the same time addressing poverty issues. Van Noordwijk (2005) defines ES buyers as any stakeholder who recognizes that environmental services are being provided, and who can be morally, legally or rationally motivated to pay for these services. The question of what motivates these buyers to pay for ES is crucial in attaining the goal of RUPES. Mulder, et al., (2006) consider the buyers or beneficiaries as the most challenging player among the market actors. They may play as 'buyers' and 'providers of rewards or compensation', but they themselves could also be modifiers of ES (Swallow, et al, 2007). While private sector and non-governmental organizations are among the prime buyers of ES, government provides both legal and programmatic interventions (Landell-Mills and Porras, 2002; ITC, 2005). 


\section{Conceptual framework}

Landell-Mills and Porras (2002) identified the major drivers for ES market development. Accordingly, demand is the main powerhouse behind ES market establishment, accounting for over 50 percent of the known major drivers (Figure 1). Examples of the specific drivers from the demand-side are: growing appreciation of the benefits provided by ES; companies' efforts to improve their public image (commonly known as corporate social responsibility); identification of niche market opportunities associated with environment-friendly products; and ethical concerns. Understanding these drivers from the beneficiaries' side will help intermediary's kickstart market development for ES.

Percent
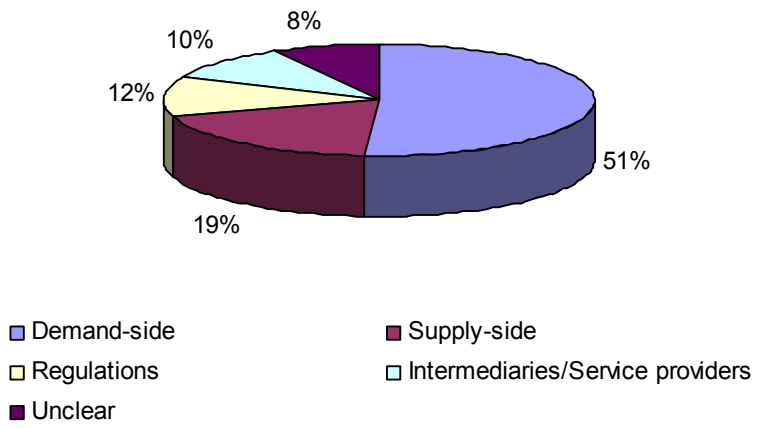

Figure 1. Relative importance of drivers for market development

(Source: Landell-Mills and Porras, 2002)

Van Noordwijk (2005) conceptualized the relationship between the potential providers or sellers of environmental services and the downstream (as interpreted in a broad sense of the flow of direction of the service) beneficiaries or buyers (Figure 2). In a market situation, the seller is the provider of the ES, e.g. upland farmers performing sustainable agricultural land use practices and/or participating in reforestation and watershed rehabilitation activities. The buyer is referred to as the beneficiary of the environmental service, e.g. water users, hydroelectric companies, bio-prospecting firms, water district, and society in general. ES buyers could come from national and global levels represented by the government, non-governmental organizations, local government units and international organizations. 


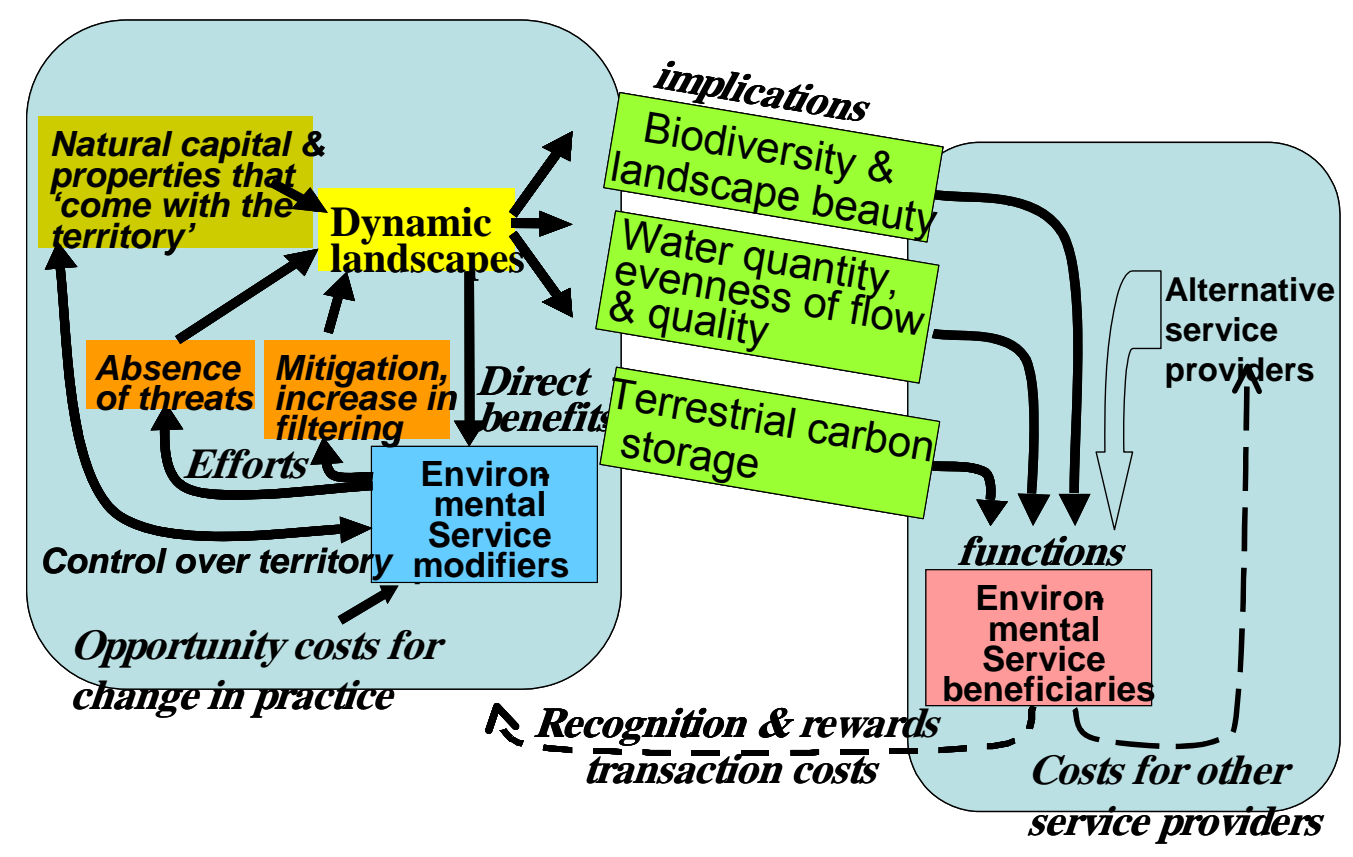

Figure 2. Relationship of the provider and beneficiaries of ES in a complex landscape (van Noordwijk, 2005).

In the Philippines, opportunities in ES markets exist. Remaining forest ecosystems are still relatively intact and are substantially supporting and providing necessary processes and services for human beings as well as other life forms. These different forest ecosystems harbor 13,000 species of plants which comprise 5\% of the world's total plant species (DENR/UNEP, 1997). About $70 \%$ of the country's total land area consists of watersheds which are important sources of water for irrigation, hydro-electric power, industrial use and household use.

Francisco (2006) identified two PES-like examples in the country. One is the Mt. Kanlaon Natural Park with La Tondeña Distillers Inc. as the buyer and a group of upland farmers as the sellers. The ES are watershed protection and biodiversity conservation. ES payment takes the form of technical assistance in agroforestry farming and provision of livelihood projects, social services, and infrastructure support. Another example is the Balian watershed in Pangil, Laguna. Francisco noted that the forms of payments are in-kind (e.g. provision of free seedlings and forest guards) which most buyers preferred, most probably due to their voluntary nature. Examples of ES cases studies that are maintaining landscape and seascape beauty are shown in Table 1. 
Table 1. Cases examined with various types of organizations and agencies in the ES market (Adopted from Boquiren, 2005).

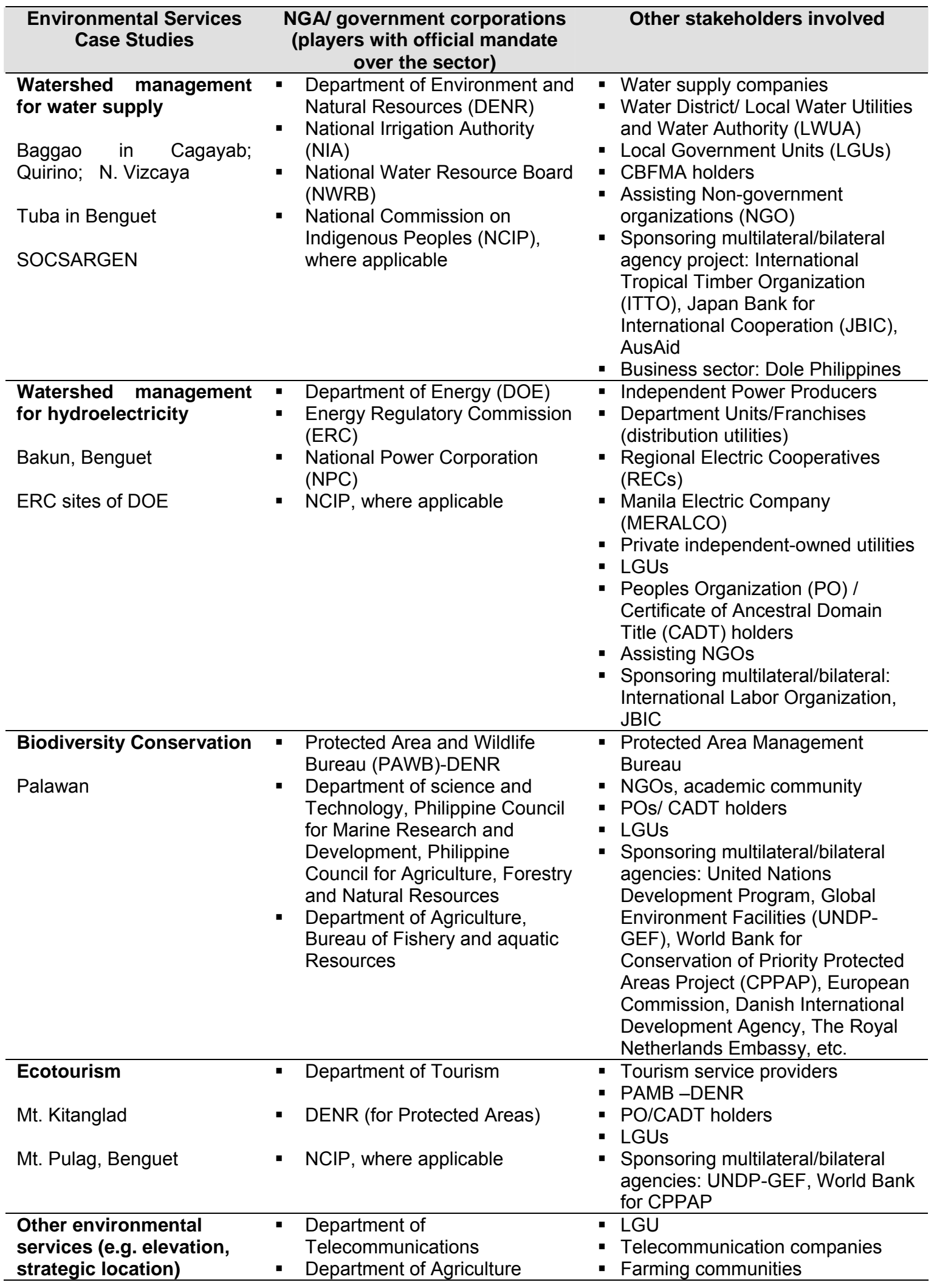




\section{Methodology}

\section{Data Gathering}

Data was gathered using the constructed survey questionnaire used by the United Nations Development Programme - Global Environment Facilities (UNDP-GEF) project on Institutionalizing Payments for Ecosystem Services, Supplement IV. Mobilizing Private Sector Buyers of Ecosystem Service (Appendix 1). The survey questionnaire was used to gain an understanding of the buyers' perspectives on ES markets and to identify opportunities and barriers in scaling-up or liberating ES markets, as well as in identifying knowledge gaps. Such information provides valuable input in facilitating the efficient provision of ES to industries, as well as improving the relationship and perceptions between the service provider and the company (Mulder et al, 2006).

\section{Scope of the survey}

A total of 120 companies were surveyed as potential ES markets, of which: 11 are engaged in greenhouse gas mitigation (e.g. carbon dioxide); 25 are involved with biodiversity market forms; 36 with landscape and seascape market forms; and 48 are engaged in water services. The majority of companies were identified through web research (e.g. travel tour websites). The companies are distributed nationwide covering the major Philippine islands. Only 25 (21 percent) were finally selected as respondents and questionnaires were either mailed or faxed to them. The remainder of companies were not included in the study for the reasons shown in Figure 3. Other companies were contacted but were not willing to undergo interviews for reasons such as requesting that data be kept confidential, requiring time-consuming formal requests to management, hesitation about the idea of PES, and showing no interest or not having the time to be involved.

\section{Responses/Reactions of Identified Companies}

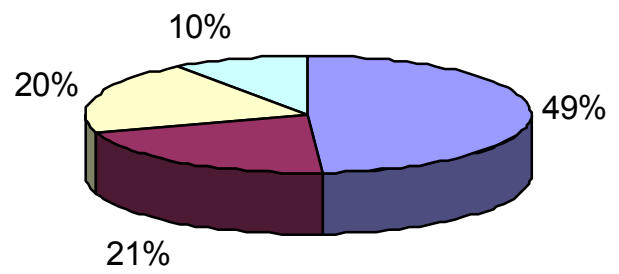

$\square$ Protected Area and no PES mechanism in placed

$\square$ Surveyed companies

$\square$ No contact information available

$\square$ Contacted but not interested to undergo survey for various reasons

Figure 3. Breakdown of companies identified for ES market survey.

Representatives from the 25 surveyed companies with possible financing schemes for environmental services were asked to respond to the questions during telephone and face-to-face 
interviews. Some of the companies completed the questionnaires via email. Of the companies surveyed, 14 (56 percent) are government-owned while 11 (44 percent) are privately-owned (Figure 4). Eight private companies chose not to participate in the survey process probably due to limited information about PES.

\section{Buyers}

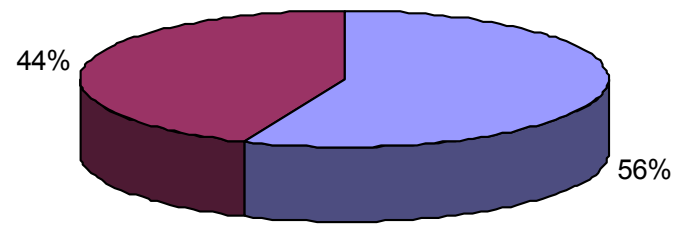

口 Government

$\square$ Private

Figure 4. Buyers of environmental services

The first round of interviews was conducted from February to March 2007, and follow-up interviews were subsequently conducted for validation purposes.

A review of literature was also conducted to further verify results of the interviews. These documents included:

PES: Sustainable Financing for Conservation and Development, Proceedings from the National Conference-Workshop on payments for Environmental Services, Direct Incentives for Biodiversity Conservation and Poverty Alleviation, Manila, March 1-2, 2005; and

PES Policy Forum Report on Costing for Environment: Implications to Policy, March 9, 2007. 


\section{Result and Discussions}

\section{Types of ES and Buyers}

Of the 25 respondent companies (Appendix 1) 14 are government-owned and most (56\%) operate in the water service sector. The 11 privately-owned companies (44\%) are involved in various ES markets, predominantly in ecotourism and biodiversity services, and the main market instruments used are eco-labeling of pharmaceutical by-products (Figure 5).

\section{Companies and ES}

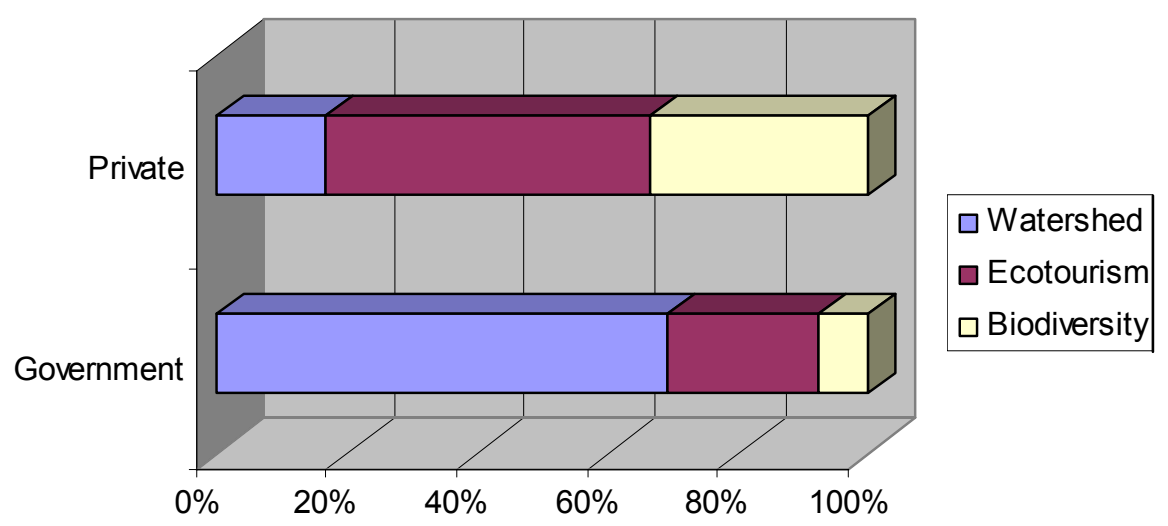

Figure 5. Percentage of companies engaged in ES markets.

Table 2 shows that the majority of ES buyers (12 companies) belong to the watershed service sector, typically in the form of water districts, followed by eight ecotourism companies involved in tour packaging and management of private nature parks, and five companies engaged in biodiversity management.

Watershed services, specifically the provision of potable water, is the predominant ES where payment schemes exist. This is expected since water has immediate relevance to the people (van Noordwijk, 2006) and has been commoditized particularly in urban areas. In addition, water is an issue with a long history of public concern. Water service is dominated by public sector ES buyers. Many local water districts in the country are either government-owned or quasi-public as the provision of water services is among the social services that local governments are expected to, or mandated to, provide to the local population. 
Table 2. Type of environmental services and demand by type of company.

\begin{tabular}{|c|c|c|}
\hline \multirow[b]{2}{*}{ Type of ES } & \multicolumn{2}{|c|}{ Type of company } \\
\hline & $\begin{array}{c}\text { Government } \\
(14)\end{array}$ & $\begin{array}{c}\text { Private } \\
\text { (11) }\end{array}$ \\
\hline $\begin{array}{l}\text { Watershed Services: } \\
\text { Drinking water provision } \\
\text { General watershed rehabilitation and soil control } \\
\text { Regular water supply for hydro-electricity via run-off- } \\
\text { the-river }\end{array}$ & $\begin{array}{l}8 \\
1 \\
1\end{array}$ & $\begin{array}{l}1 \\
1 \\
0\end{array}$ \\
\hline Subtotal & 10 & 2 \\
\hline $\begin{array}{l}\text { Landscape beauty: } \\
\text { E.g. Ecotourism }\end{array}$ & 2 & 6 \\
\hline Subtotal & 2 & 6 \\
\hline $\begin{array}{l}\text { Biodiversity Services: } \\
\text { Pharmaceutical by-products/ eco-labeling } \\
\text { In situ conservation }\end{array}$ & 1 & $\begin{array}{l}3 \\
1\end{array}$ \\
\hline Subtotal & 1 & 4 \\
\hline Total & 14 & 11 \\
\hline
\end{tabular}

One specific legal instrument that explains the observations in Table 2 is Article I of the 1987 Philippine Constitution, which states that "The national territory comprises the Philippine archipelago, with all the islands and waters embraced therein, and all other territories over which the Philippines has sovereignty or jurisdiction, consisting of its terrestrial, fluvial and aerial domains, including its territorial sea, the seabed, the subsoil, the insular shelves, and other submarine areas. The waters around, between, and connecting the islands of the archipelago, regardless of their breadth and dimensions, form part of the internal waters of the

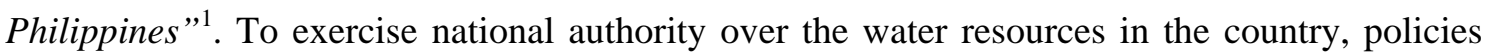
and regulations were enacted including the establishment of a water regulatory board (see Box 1) which has the authority to impose fees and issue water rights to entities who wish to engage in water servicing.

\section{Box 1. National Water Regulatory Board (NWRB)}

The NWRB was created in 1974 under Presidential Decree No. 242, as a coordinating and regulatory agency for all water resources management and development activities. It is tasked to formulate and develop policies on water utilization and appropriation; control and supervise water utilities and franchising; and regulate and rationalize water rates.

Source: www.nwrb.gov.ph

\footnotetext{
${ }^{1}$ http://www.chanrobles.com/philsupremelaw2.html accessed February 9, 2007
} 
Investment in ES by private buyers or companies has more to do with maintaining landscape beauty for ecotourism purposes. Tongson (2006) identifies two main beneficiaries for landscape beauty in the country: 1) the end-users e.g. tourists; and 2) the government (when it allocates budgets for the maintenance of natural areas such as parks, wilderness, and tourism zones). In addition, private companies that are engaged in medicinal plant production or extraction for pharmaceutical purposes are said to be buyers or investors of ES. Usually, an NGO-managed company acts as middleman to international buyers.

Private companies are not exempt from government interventions as they are mandated to comply with legal requirements to obtain business permits and are expected to meet quality standards imposed by the Philippine Bureau of Food and Drugs (BFAD). The extraction or use of natural resources is regulated under Article XII Sections $2 \& 3$ of the Philippine Constitution, which states that the government has the sole right to enter into co-production, joint venture and production sharing agreements, and to classify lands and resources that can be alienated, developed, or leased. In this case, private companies are sanctioned to venture into ES markets within the provisions of such law.

\section{Motivation and Drivers of ES Buyers}

With reference to Box 2, ES buyers respond to certain motivators and/or are driven by different factors in ES markets. Based on interviews conducted in this study, ES buyers are motivated or driven to pay, or compensate for, the provision of environmental services on the basis of the following:

Regulatory compliance -includes users' fees, access rights and license to operate, imposed by government regulatory bodies.

Direct financial business case - secured access to key natural resource inputs required for business operations.

Indirect, non-financial business case - secured license to operate or risk manage.

Ethical or environmental values of business owners, e.g. charity or philanthropic cause.

Figure 6 shows the number of companies and corresponding drivers or motivations in ES markets. Regulatory compliance and securing access to the resource are the most common drivers for engaging in ES markets. Around 80 percent of government-owned and private companies are affected by these drivers. Private firms are mostly motivated or driven by charity or philanthropic principles. 


\section{No. of Companies \& their Motivations}

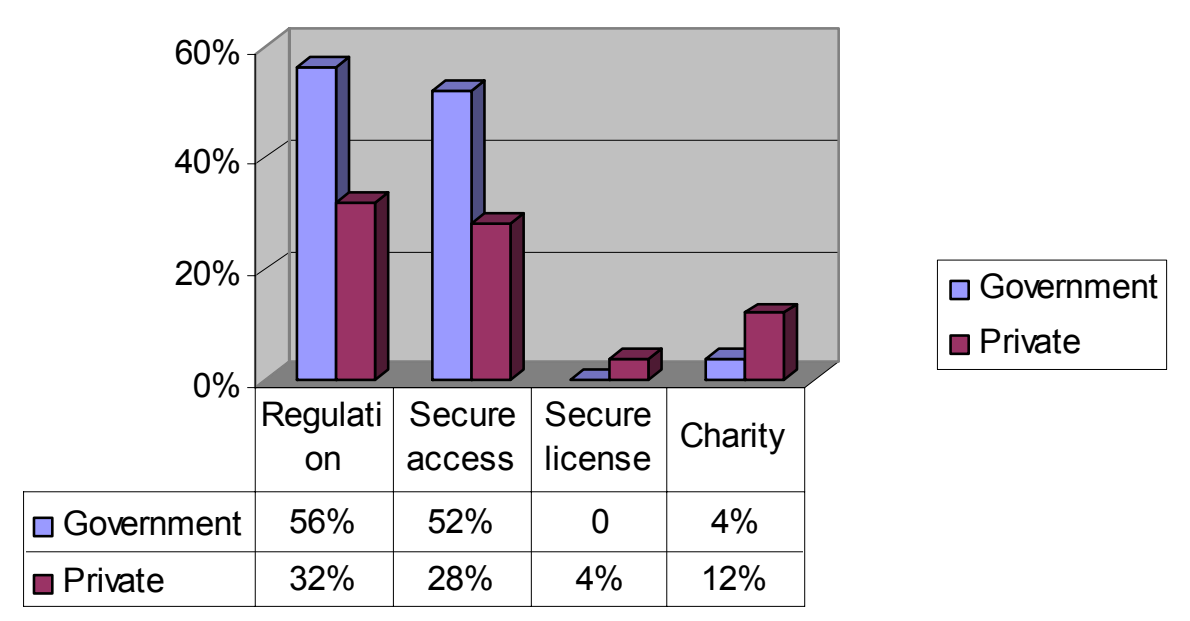

Figure 6. Number of companies and their motivations to pay for ES.

For watershed services, public sector buyers are driven primarily by regulatory compliance and the specific provision on 'share of national wealth' in the 1991 Local Government Code. These companies obtain use rights, for instance rights to draw surface water or to excavate and drill water from underground. In some cases, local resolutions and ordinances are formulated to encourage financing for use of the water resource. For instance, Section 5 of the Local Water District Law states that a local water district may be formed pursuant to this title for the purpose of (a) acquiring, installing, improving, maintaining and operating water supply and distribution systems for domestic, industrial, municipal and agricultural uses for residents and lands within the boundaries of such districts; (b) providing, maintaining and operating wastewater collection, treatment and disposal facilities; and (c) conducting such other functions and operations incident to water resources development, utilization and disposal within such districts, as are necessary or incidental to said purpose.

Under the direct financial business case, the major reasons for companies to comply with certain types of ES payments are business continuance and securing continuous supply of the resource. This most commonly involves restoration projects which maintain access to forest resources (see Box 2 for a specific example). Of these motivations (Scherr et al, 2007) types II, III, and IV are common amongst the companies surveyed in this study. 


\section{Box 2. Types of Buyers according to their motivations.}

Scherr et al. (2007) identify five types of buyers for ecosystem services who respond to different motivations:

Philanthropic buyers, who are motivated by non-use values;

Public sector buyers, at different scales, who seek to secure ecosystem services that benefit the public at large;

Private businesses, organizations or communities who engage in private deals to secure ecosystem use values or other business benefits;

Private buyers who are under regulatory obligation to offset ecological impacts; and

Consumers of eco-certified products who are motivated by both use and non-use values.

\section{The Business Case for ES}

Interviewed representatives of the respondent companies were asked whether their existing PES scheme was based on business case evidence. A total of 84 percent (21 companies) responded positively, while 16 percent perceived otherwise (Figure 7). All of the schemes are intended to ensure continued access to raw materials for production, thus ensuring the longevity of the company. Although to some extent, this idea conforms to the business case of ES, not all respondents view it as such.

\section{Strong business case for PES?}

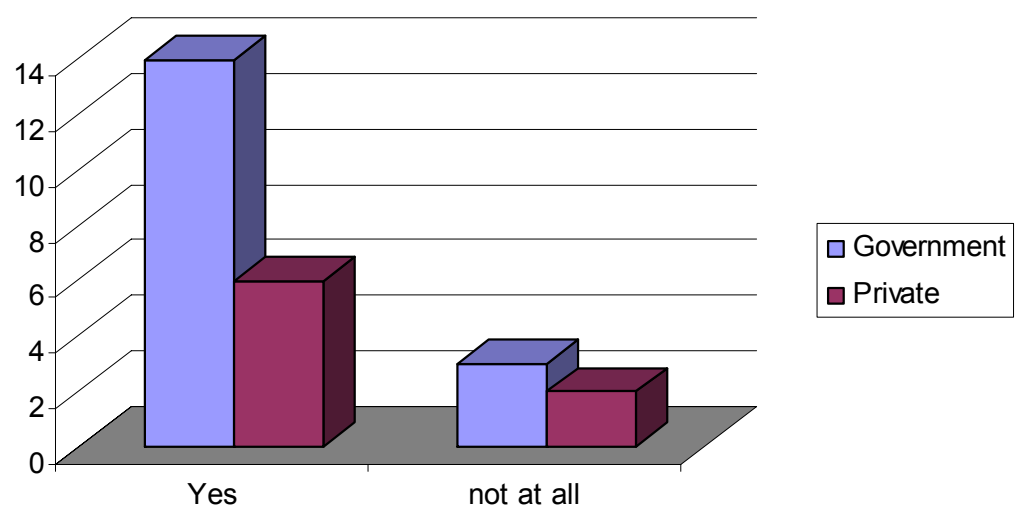

Figure 7. Response of companies on strong business case for PES

Buyers had varying responses when asked to articulate the business case for ES, several of which do not match the authors' understanding of the business case (Table 3). It is interesting to note that the concepts of 'environmental stewardship' and 'regulatory compliance' are embodied in the business case for ES in the view of respondents. 
Table 3. Responses from companies on how to articulate the business case of ES

\begin{tabular}{ccc}
\hline Ideas on how to articulate the business case of ES & $\begin{array}{c}\text { Percent of Respondents } \\
(\mathbf{\%})\end{array}$ \\
\hline - & A growing demand from the people & 43.3 \\
\hline - & $\begin{array}{l}\text { Laws (e.g. tourism law, water code) which enable } \\
\text { their business to operate }\end{array}$ & 20 \\
\hline - & $\begin{array}{l}\text { Business permits and taxes are paid, if not there is } \\
\text { no access to the resource }\end{array}$ & 6.7 \\
\hline - & $\begin{array}{l}\text { Promotion of the government specifically when } \\
\text { buyers are public sectors }\end{array}$ & 6.7 \\
\hline - & Putting something back into the environment & 3.3 \\
\hline - & Reputation with the government and clients \\
\hline
\end{tabular}

From Table 3, it can be seen that none of these responses refer to any direct expectation of conditionality or enhanced ES supply.

Clearly, the respondents have different views on the business case for PES. For instance, one respondent said that PES has a business case if they complied with mandatory fees, business permits and taxes. To probe some plausible arguments on the differing views of respondents, the companies that saw a business case in PES were further asked to elaborate on their case. One respondent commented that there is a business case in PES "if there is a growing demand coming from the end users, if there is none then, it will be useless to invest in ES markets". Others mentioned "market location" and "available financial capital" as factors to consider in making a strong business case in ES. One respondent from a water company said that, "currently, the water supply is greater than the demand, but we foresee that in the near future, demand will increase and PES is one of our considerations". It is interesting to note that one water district mentioned they had encountered a water shortage in the past but that it had been resolved by increasing the water pressure and interconnecting water pipes from low producing wells to high producing wells. The district seemed unclear of the business case for PES.

On the other hand, ES buyers (respondents) who were unconvinced of the business case for PES had the following views: 1) PES are just mandated by law to protect the environment so buyers have to comply with such laws (10 percent); 2 ) donating to watershed services and landscape beauty is only a form of advocacy (3.3 percent); and 3) it is only part of an environmental awareness drive (3.3 percent). These comments do have a basic logic, since government regulations sometimes limit the potential of ES markets.

\section{Setting-up ES Markets and Upfront Costs}

Development of ES markets is neither simple nor uniform. It may evolve within existing institutional frameworks and entail a variety of formal and informal rules, and codes of conduct (Landell-Mills and Porras, 2002). Also, the process of developing ES markets can be complex, long and tedious. The companies surveyed identified the following activities in setting up ES markets.

1. Taking advantage of opportunities created by new alternatives. Potential buyers usually spend money and time in collecting information. Some invest in clarifying the science that underpins market design. Costs for data collection and capacity building are incurred at this stage. 
2. Conducting a feasibility study. Once the science is clear, market feasibility is investigated. This includes cost-benefit analyses, including transaction costs.

3. Creating ordinances and resolutions. Within an existing institutional framework, a market can evolve through regulatory arrangements. Costs incurred include those associated with conducting meetings, public hearings and consultations with different government units and other stakeholders.

4. Establishing Memorandum of Agreements (MOAs). An MOA is as binding agreement between ES beneficiaries and providers. Costs are incurred in the negotiation and communication processes undertaken until signing occurs.

5. Undergoing a bidding process to lease or apply for a concession agreement. This usually happens when the government is privatizing goods or a service. The costs may vary depending on how the bidding process is conducted and the type of lease/concession agreement.

Based on the study, companies incurred upfront costs ranging from $\mathrm{PhP} 500$ to $\mathrm{PhP} 6$ million depending on the ES involved, the location, demand and the establishment process. For water services, feasibility studies are commonly conducted before the market is established. It was observed that the upfront cost is lower if the land or area covered has a secured property right, either individually or collectively, depending on the nature of the ES markets. Although a biodiversity market is sanctioned under the Philippine Anti-Biopiracy Law, the market may evolve without formal or informal rules. For instance, one private company is using indigenous communities to propagate endemic plants on one of the countries remote islands. Once the plants produce seed, the company directly buys the seed from the community. These are then packed and exported to Japan. During an interview with one of the company's employees, it was revealed that the company did not have a business permit or license to operate, however the company is generating income and employing a number of staff. This case is consistent with the payments for ES concept in the company's view, and they may desire some form of legitimacy by referring such mechanism (e.g. bioprospecting rules).

\section{Payments and forms of securing ES}

Most of the respondents perceived tax payments, wages, salaries of staff and laborers, and direct payments to the municipal treasury as means of paying for environmental services which suggests a misunderstanding of the PES concept. Instead, the payments they make are part of production inputs, such as staff and labor costs, which have no direct effect in securing ES provisions. Other examples of payment schemes are discussed below.

Watershed Services. Under Philippine law, buyers of water services are required to obtain water rights before a business is considered legal. Annual payment is made to the NWRB depending on the volume of water that can be pumped out or drilled from the service area. Some companies pay additional fees such as a concessionaire fee and local government taxes. Specific examples include the following:

- A water bottling company is paying NWRB an amount of \$103 USD (PhP 5000) annually for access to a source of natural spring water.

- A water service company pays a concessionaire fee amounting to \$12.3 million USD (PhP 600 million) annually to the Metropolitan Waterworks and Sewerage System (MWSS). 
- A municipal waterworks system is exempt from paying annual dues to the NWRB since the land they operate on was donated by private individuals and is currently managed by the LGU. The donors, who are locals, are compensated by the waterworks system through exemption from water service charges and protection of the watershed.

- A private camping enterprise pays $\$ 41$ USD (PhP 2000) annually to NWRB for the use of river flowing inside the recreational facility.

- The National Power Corporation (NPC) sets a separate fund for reforestation and conservation activities (based on the 1991 Local Government Code). People's Organizations (POs) may submit project proposals to access the fund.

Landscape beauty. Tourists usually make payments in the form of entrance fees and donations, however this is not generally understood by buyers or customers (tourists) as a form of PES. Some companies have also acted as intermediaries for PES, in the context of corporate social responsibility (CSR). For example, the Lamesa EcoPark is owned and operated by the ABSCBN Foundation ${ }^{2}$ which has generated funding through donations from individuals, groups and companies supporting the foundation's environmental protection program (e.g. Bantay Kalikasan). Managed by a television company, the Lamesa EcoPark receives extra mileage from media exposure, making it easier to entice corporate support. The EcoPark serves as a 'honeypot' where corporate entities contribute financial resources motivated by CSR principles. Another example is a private nature park which was delineated under the Industrial Forest Management Agreement (IFMA) of the Department of Environment and Natural Resources (DENR) covering 1,920 hectares of mixed land-uses. The park lessee pays PhP 0.50 per hectare for the first six years and $\mathrm{PhP}$ 1.50/hectare for each subsequent year. Another private camping enterprise with recreational facilities pays the Bureau of Internal Revenue (BIR) business and income taxes amounting to \$972 USD (PhP 47,000) annually.

Biodiversity. For biodiversity, PES schemes are often unclear, however business permits and farmers' salaries and wages, which ensure continued access to resources (e.g. replanting of medicinal plants), are typically viewed as forms of ES payments. Some examples are discussed below.

- The Subic Bat Kingdom, managed by the Haribon Foundation, is generating funds through donations and grants from various research and financial institutions. Other income sources include entrance fees ( $\mathrm{PhP} 20$ ) and the Subic Bay Metropolitan Authority, which allocates regular funds to maintain the office and pay staff salaries.

- Capacity building through training is also provided to farmers to ensure they engage in herbal plant production. The plants harvested by farmers are then directly purchased by the buyers who are providing the training.

These examples show that most of the transactions have government involvement through taxes and mandatory regulations, suggesting that these PES or PES-like cases are not truly voluntary. In addition, the real service providers are unclear about the question of 'Who should the buyer really pay?' This may suggest that PES can still be made clear even if the government imposes taxes and regulations, however drivers and motivations (which are different for each buyer) are seen as one important factor in developing a real PES.

\footnotetext{
${ }^{2}$ ABS-CBN is a private television company.
} 


\section{Gains and Profits from selling ES}

Seven companies were willing to share information on profits gained from engaging in ES markets. The average profits from these seven companies ranged from $\mathrm{PhP} 20,000$ to $\mathrm{PhP} 4$ billion based on annual sales.

Table 3 shows that the biggest earners are the privately-owned water companies, with PhP 530 million spent on securing services. Of this amount, 90 percent is used for water treatment and wastewater recycling and 10 percent for watershed rehabilitation. Accordingly, this allocation is based on the argument that the company's primary mandate is wastewater management, and that watershed management and rehabilitation is the responsibility of the DENR. The company's performance is evaluated on the basis of good sanitation and wastewater management, not necessarily on watershed management. Non-compliance would result in termination of permits by the government's regulatory office ${ }^{3}$. As of 2006, the company's net profit was approximately $\mathrm{PhP}$ 2,300 million which makes them the top earner of all the respondent companies.

Table 3. Example of profits from engaging in ES markets (approximated values).

\begin{tabular}{lcrrr}
\hline \multicolumn{1}{c}{ ES Buyers } & $\begin{array}{c}\text { Upfront cost } \\
\text { (PhP) }\end{array}$ & $\begin{array}{c}\text { Recurrent cost } \\
\text { (PhP) per year }\end{array}$ & $\begin{array}{c}\text { Amount to } \\
\text { secure ES } \\
\text { (PhP) per year }\end{array}$ & $\begin{array}{c}\text { Average } \\
\text { Gross Revenue } \\
\text { (PhP) as of 2006 }\end{array}$ \\
\hline $\begin{array}{l}\text { Private water } \\
\text { company* }\end{array}$ & NA & $4,500,000,000$ & $530,000,000^{4}$ & $6,800,000,000$ \\
\hline $\begin{array}{l}\text { Provincial Water } \\
\text { District A }\end{array}$ & NA & 25,000 & $183,000^{\delta}$ & $1,000,000$ \\
\hline $\begin{array}{l}\text { Provincial Water } \\
\text { District B* }\end{array}$ & $3,000,000$ & $<100,000$ & 3,000 & $2,800,000$ \\
\hline Biodiversity Buyer A* & NA & 250,000 & $450,000^{\delta}$ & $3,500,000$ \\
\hline Landscape Buyer A* & $7,000,000$ & 77,000 & NA & $>20,000$ \\
\hline Landscape Buyer B & NA & NA & NA & $2,000,000$ \\
\hline Landscape Buyer C* & $1,000,000$ & 270,000 & NA & 500,000 \\
\hline
\end{tabular}

Legend: $\mathrm{NA}=$ not available

In contrast, a provincial water district is allocating 0.1 percent $(\mathrm{PhP} 3,000)$ from its total gross profit to secure watershed services annually. The payment is in the form of voluntary assistance for the maintenance of spring water. It was observed that the surroundings of the spring water are in relatively good condition and water supply is said to be higher than demand. The company has been exempted from paying water rights from the NWRB as the water source was donated by private individuals.

Although the business case for PES is recognized by the majority of respondent companies, the information gathered from these companies did not suggest that paying for, or investing in, ES to secure the supply is profitable. Although the businesses are making money, this cannot be attributed to their PES schemes. This poses a new challenge of liberating the ES markets. Questions such as 'What are the constraints?' and 'What needs to be done?' will be addressed in

\footnotetext{
${ }^{3}$ The Company is under the concession agreement with the MWSS as the government regulatory office.

${ }^{4}$ Majority (90 percent) of the amount goes to water treatment and wastewater recycling.

* Company names were changed.

${ }^{\delta}$ Amount used to pay workers or laborers to deliver ES.
} 
the next section of this paper.

\section{Liberation of ES Market}

As mentioned above, the majority of companies expressed, that in their view, there is a strong business case for PES, but it remains hard to ascertain the plausible links between PES and profits. The companies alluded that the availability of policy information and strict enforcement will likely accelerate the process of market liberation for ES (see Box 3).

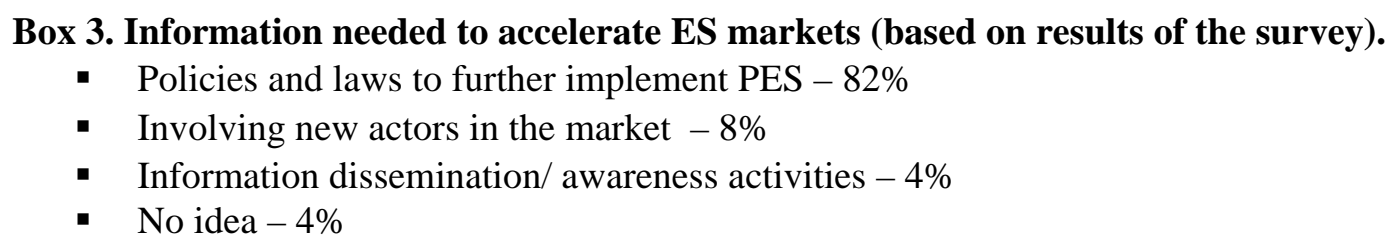

\section{Constraints for ES Market Liberation}

Despite the growing popularity, and recognition of, ES benefits, there are market, institutional and policy failures which constrain the development of ES markets. Most ES fall into the category of positive externalities or public goods (Cornes \& Sandler, 1996) and the majority are considered uncompensated benefits. Knowledge and perception gaps exist between the ES beneficiaries and ES providers, complicating the development of ES markets. For example, a respondent from one company observed "the water is not really coming from the forest but from the ground" while another respondent commented "there is no scientific evidence that trees provide water but it helps in reducing sediments and soil particles in the water flowing from the spring." The common perception in public discourse is still that planting tress will enhance water flows.

Wunder (2005) defines PES as a voluntary transaction of a well-defined ES which is being bought by at least one ES buyer from at least one ES provider, if and only if, the ES provider secures ES provision. This definition has clear links to the criteria of the RUPES concept, namely: voluntary, conditional pro-poor and realistic. Following this definition, and considering the three criteria of RUPES, the above business cases as perceived by current buyers do not conform to the real PES concept, or at best, its infant stage.

There is enormous potential for PES if market failure is addressed. Although the respondent companies do not present a perfect case for PES, some homegrown strategies appear to be functional and delivering profits to companies. To address the constraints mentioned earlier, the concept of commoditization of ES is proposed and discussed.

\section{Commoditization - An approach to market ES?}

A commodity is a tangible product bought and sold in a market transaction. To turn ES into a commodity is the key to making it saleable in the market. To develop this, the taxonomy and nature of rivalry and excludability of potential ES (as two main criteria for defining public and private goods) must first be identified and understood. By definition, rivalry implies that the consumption of a service by one individual will reduce the amount available to others. On the other hand, excludability means that only limited numbers of consumers can enjoy the service 
because they pay for the privilege (Landell-Mills and Porras, 2002). Public goods are characterized as non-excludable and non-rival while private goods are goods with high excludability and high rivalry. Goods that are excludable, but have low rivalry are called toll goods while goods that have high rivalry, but are non-excludable are called common pool goods. We can look at the degree or levels of rivalry and excludability of each identified ES based on the following.

- A good or service is rival if one person's consumption of a unit of a good diminishes the amount of the good available to the consumer or buyer.

- A good or service is excludable if it is feasible and practical to selectively allow the consumer or buyer to consume the good.

From these descriptions, the characteristics of various ES is defined in Table 4 (whether public or private). For example, the general watershed function of rehabilitation for soil control as an environmental service, benefits anyone in or near the area. It is difficult to extract a fee from everyone in the area, and so this ES will not be funded by the private sector but by the public sector. The condition is the same for the surveyed cases on regular water supply, local pharmaceutical by-products and in situ conservation. Ecotourism, on the other hand, has both public and club service ${ }^{5}$ characteristics. This is because some of the ecotourism examples in the study require user fees (e.g. entrance fees) to consume or enjoy the service while others are open and free for the public, with the public sector being the one financing it.

Table 4. Degree of rivalry and excludability of the ES.

\begin{tabular}{|c|c|c|c|}
\hline Types of ES & Rivalry & Excludability & $\begin{array}{c}\text { Types of } \\
\text { Goods/service }\end{array}$ \\
\hline \multicolumn{4}{|l|}{ Watershed Services: } \\
\hline a) Drinking water provision & High & High & Commodity* \\
\hline $\begin{array}{l}\text { b) General watershed rehabilitation } \\
\text { for soil control }\end{array}$ & Low & Low & Public service \\
\hline $\begin{array}{l}\text { c) Regular water supply for hydro- } \\
\text { electricity via river run-off }\end{array}$ & Low & Low & Public service \\
\hline \multicolumn{4}{|l|}{ Landscape beauty: } \\
\hline Ecotourism & Low & High & Public/Club service \\
\hline \multicolumn{4}{|l|}{ Biodiversity Services: } \\
\hline $\begin{array}{l}\text { a) Pharmaceutical by-products/eco- } \\
\text { labeling }\end{array}$ & Low & Low & Public service \\
\hline b) In situ conservation & Low & Low & Public service \\
\hline
\end{tabular}

*Could be treated as commodity in cases of bottled water from mineral springs

Van Noordwijk (in progress) develops a concept of ES commoditization of the environment as a basis for PES (Figure 8). Accordingly, markets operate well in the excludable, rivalrous corner, especially for consumable commodities. Markets also function well when stocks or assets (e.g. natural, social, financial, physical, human) are converted into flows (e.g. monetary cash flows). Commoditization of ES happens when there is an increased level of rivalry and excludability and when stocks are shifted to flows.

\footnotetext{
${ }^{5}$ Club goods will further discuss in the next subsection.
} 


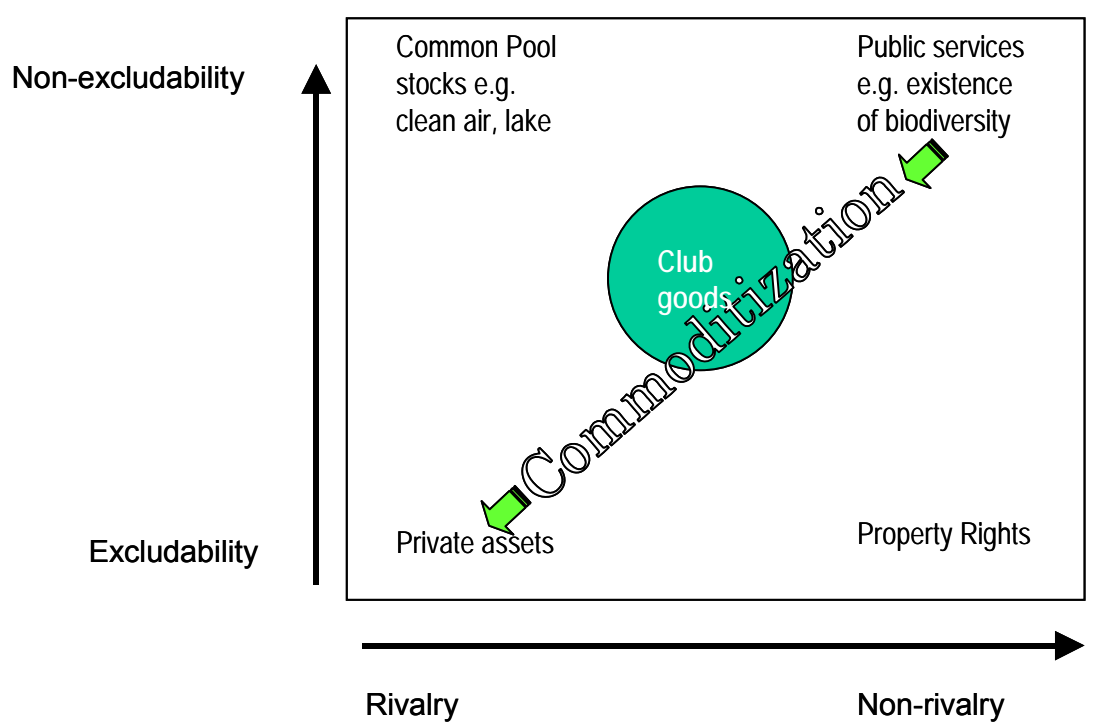

Figure 8. Concept of commoditization to market environmental services (van Noordwijk in progress).

According to Landell-Mills and Porras (2002) the dynamic nature of rivalry and excludability underpins changes in the public or private status of goods and services. Taking the examples of ES in Table 4, the only ES that is considered a commodity is the provision of drinking water. In the ensuing examples, water was viewed as a public good (free use) which became a commodity when its access was controlled due to water crisis (as a result of over increasing demand). Privatization, or local water district development, whether operated by private or government institutions, increased the excludability of the service.

The other identified ES have low rivalry and excludability characteristics. The challenge will be to convert these services into commodities which can be bought and sold in any market. Landell-Mill and Porras (2005) suggest that increasing the demand for services raises the rivalrous nature of such services. The interviewed companies conformed to the idea of rivalry and agreed that a growing demand for ES is a precondition to accelerating the liberation of ES markets (see business case).

\section{Club goods}

By definition, club goods or toll goods are goods or services that are excludable but non-rival. Humpreys (2006) explains that individuals can gain entry to a club for payment of a fee or toll. For some club goods, there may be an element of rivalry among users. According to Humpreys (2006) a protected area becomes a club good when people pay a fee to gain temporary access to the forest. Where no fee is charged and members of the public enjoy free use, the forest in question is in effect a public good. Where a protected forest area is not effectively secured, so that outsiders can enter the forest and exploit it for free, then that forest has a res nullius (open access) character.

Van-Noordwijk (in progress) has expounded on the topic of club goods in the case of atmospheric concentration of greenhouse gasses. Since climate affects everyone, it is considered non-excludable and has a non-rivalrous nature, making it difficult to deal with in the marketplace. Creating Carbon Emission Reduction Certificates has made carbon trading 
possible. The process involved the 'cap and trade' regulation which created a rivalrous carving up of sustainable emission space and certification within a set of rules created by a new club (i.e. countries that ratified the Kyoto Protocol). The market for carbon sequestration would have no chance of existing without the 'club' setting the rules for the market.

Van-Noordwijk mentions that many PES cases are dealing with direct access to clean water as the basis for a commodity stream and most of them have a 'club' character. The spatial limitations to water flows create a logical boundary to what the community can perceive. Most 'willingness to pay' instruments are linked to future flows, these being the benefits on offer to the members of a club which excludes 'free-riders'. The concept of club goods offers a new discussion for marketing ES, however additional work is required to verify its applicability to marketing ES.

Drawing on cases from different parts of the world, Landell-Mills \& Porras (2005) identified key commodities that can be derived from ES, making them attractive and easier to market. Table 5 lists key commodities that may be applicable in the Philippines and which can be further explored using the concept of 'club goods'.

Table 5. Recommended commodities used to market ES (adopted from Landell-Mills \& Porras (2005) and based on the results of this survey).

\begin{tabular}{lll}
\hline \multicolumn{1}{c}{ Category } & \multicolumn{1}{c}{ Services } & \multicolumn{1}{c}{ Commodities } \\
\hline Biodiversity & Ecosystem, insurance, choice,, & Biodiversity-friendly products \\
option and existence values & Bioprospecting rights \\
& Conservation easements \\
& Development rights \\
& Land lease/conservation concessions \\
& Land acquisitions \\
& Management contracts \\
\hline Water services & Water quality and regulation & Protected areas \\
& & Research permits \\
\hline Landscape beauty & Watershed protection/best management \\
& practice contracts \\
& Conservation easements \\
& Land acquisition/leases \\
& Scenic beauty & Water rights \\
\hline Carbon offsets & Access rights/permits \\
& Management agreements \\
& & Land lease/concessions \\
& & Land acquisition \\
& Carbon sequestration & Package tour/tourism services \\
\hline
\end{tabular}

One recommendation ${ }^{6}$ in order to increase private financing is to increase the level of excludability of a service through applying or improving the technology, especially in the case of developing biodiversity-friendly products. In addition, stricter enforcement of property rights will reduce instances of 'free-riding'. This is applicable in the areas of commoditizing biodiversity (e.g. biodiversity rights, land conservation lease/concession), water services (e.g. water rights), and landscape beauty (e.g. access rights/permits, land acquisition). In the Philippines, cooperatives, community based-forest management and other similar club-like groups already exist and can be explored to increase the level of excludability of the ES through establishing rules and strategies (e.g. applying technologies).

\footnotetext{
${ }^{6}$ Source: Public-private good analysis (http://www.deliveri.org/Guidelines/misc/proj_papers/pp_9.htm)
} 


\section{Role of Competitors}

Generally speaking, beneficiaries will be more inclined to pay for very specific services as opposed to general conservation services. In identifying beneficiaries, it is important to identify potential free-riders that could benefit from the provision of services without contributing to the PES system. This may affect contributors' support for the PES scheme and possibly lead to their withdrawal. Payments or rewards benefit competitors through free-riding. The following specific examples were encountered from the surveyed companies.

- Owners of private cottages are free-riding with the water and landscape services by not paying or participating in the LGUs conservation and protection efforts.

- For private water companies, competitors include companies and large buildings that have large deep wells or rainwater tanks and do not have water system lines. To manage this type of competition, the private water company will offer to establish water system lines free of charge.

- Water districts consider private water-purifying stations as their main competitor. These stations treat water from the water districts’ lines and sell it for a higher price.

Competition also exists between government-run ES markets and private companies when the latter offer a lower price for the same commodity. 


\section{Conclusions}

Based on the study, pure PES rarely exists. Tax payments and compliance to government regulation is misconstrued as PES, which could have positive ramifications for viable and pure PES schemes. The majority of respondents in this study showed limited understanding of the PES concept hence the need to raise awareness of the concept. Despite this, several PES-like schemes exist in various forms and manifestations, from very simple to complicated (e.g. riding on various institutional frameworks to commercialize ES). A bigger typology of PES, which includes PES-like schemes that possess distinct characteristics at each level or degree, could be developed to better understand the behavior of different actors.

The business case for ES is apparent but it involves many different factors beyond the security of supply of ES. Although not all ES could be easily commoditized, in general commoditization as an approach for marketing ES offers new opportunities. The concept of commoditization of ES needs to be properly understood, not only by buyers, but also by sellers, as the latter influence the business case for PES. This aspect is an important area for future research. In addition, the development and implementation of ES markets entails a wide range of relative costs. It would be interesting to determine the relative costs viz-a-viz total production costs of a certain ES, which may determine its value. There are also factors that were mentioned in this study which influence market creation for ES such as demand and supply potential, value and significance of the service, geographical location of the market, and ease of defining and enforcing property rights.

The need for government intervention through laws and policies was recognized in order to accelerate the liberation of ES markets. Respondents also cautioned about poor implementation of many laws and policies and there was concern about the transparency of government spending on ES payments. Finally, respondents accepted that they are still in the learning process when it comes to ES.

In summary, everything up to this point is academic unless there are willing buyers of ES and pure PES schemes are developed and implemented. It is also necessary to ascertain whether the identified beneficiaries or users of ES can be transformed into buyers (Johnson et al, 2001). 


\section{References}

Boquiren, R. 2005. Legal, policy and institutional framework for payments for environmental services in the Philippines: opportunities and challenges in the forestry sector. In Padilla, J. E., et al (eds.) PES: Sustainable financing for conservation and development: Proceedings from for Biodiversity Conservation and Poverty Alleviation, Manila, March 1-2, 2005, WWF, ICRAF, REECS, UP-CIDS, UPLB-ENFOR, CARE. 88p.

Cornes, R. and T. Sandler. 1996. The theory of externalities, public goods and club goods ( $2^{\text {nd }}$ ed.) Cambridge: Cambridge University Press. 590 pp.

Costanza, R., d'Arge, R., deGroot, R., Farber, S., Grasso, M., Hannon, B., Raskin, R.G., Sutton, P., van den Belt, M. 1997. The value of the world's ecosystem services and natural capital. Nature 387, 253-260.

DENR/UNEP (Department of Environment and Natural Resources /United Nations Environment Program). 1997. Philippine Biodiversity: An Assessment and Action Plan, Makati City, Philippines, Bookmark Inc.

Francisco, H. 2005. The what, the how, the why, and the where of environmental services payments. In Padilla, J. E., et al (eds.) PES: Sustainable financing for conservation and development: Proceedings from for Biodiversity Conservation and Poverty Alleviation, Manila, March 1-2, 2005, WWF, ICRAF, REECS, UP-CIDS, UPLB-ENFOR, CARE. 24p.

Humpreys, D. 2006. Public goods, neoliberalism and the crisis of deforestation. Paper presented to the Annual Conference of the British International Studies Association, 18-20 December, University of York.

ITC. 2005. Exporting environmental services - the buyer's perspective. Paper contributed for the Executive Forum on National Export Strategies. 5-8 October 2005, Montreux, 4p.

Johnson, N. White, A. and Perrot-Maître, D. 2001. Developing markets for water services from forests: issues and lessons for innovators. Katoomba Group, World Resources Institute and Forest Trends, Washington DC

Landell-Mills, N. and Porras, T. 2002. Silver bullet or fools’ gold? A global review of markets for forest environmental services and their impact on the poor. Instruments for sustainable private sector forestry series. International Institute for Environmental and Development, London.

Mulder, I., ten Kate, T., Scherr, S. 2006. Private sector demand in markets for ecosystem services: preliminary findings. Adapted from full report submitted to the UNDP-GEF project: "Institutionalizing Payments for Ecosystem Services, supplement III. Mobilizing Private Sector Buyers for Ecosystem Services"

Scherr SJ, Milder JC and Bracer C. 2007. How important will different types of compensation and reward mechanisms be in shaping poverty \& ecosystem services across Africa, Asia \& Latin America over the next two decades? CES Scoping Study Issue Paper 5. ICRAF Working Paper no. 40. Nairobi, Kenya: World Agroforestry Centre. 12p.

Swallow BM, Kallesoe M, Iftikhar U, van Noordwijk M, Bracer C, Scherr S, Raju K, Poats S, Duraiappah A, Ochieng B, Mallee H and Rumley R. 2007. Compensation and rewards for environmental services in the developing world: framing pan-tropical analysis and comparison. ICRAF Working Paper no 32:56p.

van Noordwijk, M. 2005/2006. Rapid hydrological appraisal (RHA) of potential for environmental service rewards: procedure and application in Lake Singkarak, West Sumatra, Indonesia. ETFRN News, No. 45-46 winter. 49p.

van Noordwijk, M. 2005. RUPES Typology of Environmental Service Worthy of Reward. Bogor: World Agroforestry Centre.

Wunder, S. 2005. Payments for environmental services: some nuts and bolts. Occasional Paper No. 42. Center for International Forestry Research. Bogor. 24pp 


\section{Appendix}

Questionnaire: Understanding the drivers and motivations for companies to pay for ecosystem services and determine opportunities to increase private PES in the future

Company name:

Person name:

Date:

Place:

1. PES deal:

a. What ecosystem service is being paid for?

b. Who is/are the seller(s)?

c. How much has been paid / what is the financial arrangement with the seller of the ecosystem service?

d. How did the deal take place?

e. How much land is involved with the deal?

f. Is there a public document on this deal?

2. What was the motivation for making this payment [of the ecosystem service]?

- Regulatory compliance (i.e. law, international convention)

- Business opportunity (e.g. financial intermediaries in the carbon market)

- Securing business continuance

o Access to certain resource (water, "charismatic" macro fauna, bioprospecting)

o Security of supply (e.g. conservation of watershed to secure water flow regulation, water quality)

- Securing license to operate / Risk management

o Better relations with regulators, supporting formal license to operate in the future.

o Better relations with local communities, supporting informal license to operate.

o Improving the "green environmental" image of the company

- Charity / Philanthropic

- Other motivation, namely....

3. To what extent was the payment linked to the business case? Do you believe there is a strong business case for PES? If so, how would you articulate it?

4. What part of the payment is being used for conservation / securing the ecosystem service?

5. Was the government involved in establishing the deal / payment scheme?

6. Has the agreement delivered the anticipated advantages to the company? Is there scientific evidence that the ecosystem service delivers what has been paid for?

7. Do you believe that this deal also benefit your competitors (i.e. enhancing free-riding)?

8. Do ecosystem benefits of private sector PES also provide public benefits? Or do they compete or diminish?

9. What has the company learned from the experience?

10. What (information) is needed to accelerate the liberation of markets for ecosystem services?

Thank you for your time and your cooperation with our project!! 


\section{Who we are}

The World Agroforestry Centre is the international leader in the science and practice of integrating 'working trees' on small farms and in rural landscapes. We have invigorated the ancient practice of growing trees on farms, using innovative science for development to transform lives and landscapes.

\section{Our vision}

Our Vision is an 'Agroforestry Transformation' in the developing world resulting in a massive increase in the use of working trees on working landscapes by smallholder rural households that helps ensure security in food, nutrition, income, health, shelter and energy and a regenerated environment.

\section{Our mission}

Our mission is to advance the science and practice of agroforestry to help realize an 'Agroforestry Transformation' throughout the developing world.

\section{F U T UR E ڤै HA RY/ES T CGIAR}

A Future Harvest Centre supported by the CGIAR

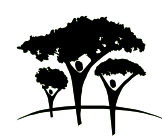

United Nations Avenue, Gigiri - PO Box 30677 - 00100 Nairobi, Kenya Tel: +254 207224000 or via USA +1 6508336645

Fax: +254207224001 or via USA +16508336646

Southeast Asia Regional Programme - Sindang Barang, Bogor 16680 PO Box161 Bogor 16001, Indonesia

Tel: +62 251625415 - Fax: +62 251625416

www.worldagroforestry.org 